\title{
Voices from the EAST: SVETlana Alexievich'S AND HANNA KRALL'S LITERARY JOURNALISMS ${ }^{1}$
}

\author{
Mateus Yuri PAssos ${ }^{2}$ and Arthur BReCCIO MarChETto ${ }^{3}$
}

In literary journalism, just like in fiction, reality is organized in ways that reflect the authors' worldviews. Their choices in style and structure often result in unique ways for the reader to virtually experience the events told in reportages. Based on a close reading of excerpts from three books - one by the Polish writer Hanna Krall and two by the Belarusian reporter Svetlana Alexievich - we intend to understand features peculiar to literary journalism produced by Slavic women. Our goal is to identify the singularities in style and voice in each author's work, as well as their narrative and discourse strategies. In our findings, we understand that Svetlana Alexievich tends to present a mosaic of individual experience for the reader to grasp a broader sense of reality, while Hanna Krall's style is full of narrative discontinuities and gaps of information, an approach she believes is more truthful in emulating reality as it is experienced by her subjects.

1 Our many thanks to Jan-Miklas Frankowski from Uniwersytet Gdański, who has first introduced us to Hanna Krall's works and has shed some light on the peculiarities of her style.

2 Mateus Yuri Passos is full professor at the Graduate Program in Social Communication at Universidade Metodista de São Paulo, Brazil, with a BA in Journalism from the same university.

3 Arthur Breccio Marchetto is a PhD candidate at the Graduate Program in Social Communication at Universidade Metodista de São Paulo, Brazil.

Recherches en communication, $\mathrm{n}^{\circ} 51$ - Article publié le 10/09/2020 
In his introduction to Literary Journalism Across the Globe, John S. Bak (2011) ponders the difficulties of finding a singular definition for literary journalism or of classifying it as a genre or form, since the approaches authors take vary widely around the world and over the decades. Even during the 1960's, in American New Journalism there were at least two radically different approaches, coined by David Eason (2008) as "realist" and "modernist" modes. "Realist" was a mode in which authors (e.g. Gay Talese, Tom Wolfe, Truman Capote) attempted to depict reality as something external to them, and behave like observers, reporters of established facts. "Modernist", on the other hand, was a mode in which authors understood reality as something that could not be reached through objectivity, and behaved like interpreters of people and events (e.g. Joan Didion, Hunter S. Thompson, Norman Mailer).

The distinction between approaches is usually discussed as pertaining to the realms of ethics - e.g., by considering interpretive reporting a blurring or distortion of real events, or on the other hand to consider "realist" reporters as naïve or perfunctory in their belief that it is desireable to depict reality "as it is", i.e., that it actually would be possible to perceive reality "as it is".

However, there is another aspect underlying that distinction, since the way a reader would experience a "realist" reporting would differ considerably from the way they would experience a "modernist" piece, which is something that Eason (2008, p. 199) alludes to in that seminal essay: "Realist reports represent style as a communication technique whose function is to reveal a story that exists 'out there' in real life. Modernist texts represent style as a strategy for conceiving as well as revealing reality". In this sense, style is also a way for creating a sense of reality, a sense of experiencing reality.

As Caracciolo (2014) has noted, experientiality in narrative is not only expressed in the life experience of characters, but also the way the readers experience the narrative through style, and in our particular case, how a reader experiences narrative that is intended - and expected - to truthfully portray reality. As evident throughout our discussion, the relationship of truthfulness to reality may vary wildly even among literary journalists. Stylistic approaches that tend to 'blur' reality and present it through deeply personal interpretation - even as construction-might actually be the ones that, according to the authors who prefer them, are the most faithful to how people actually experience events in their lives. 
In this paper we aim to identify the uniqueness in the narratives of two major Slavic reporters, Hanna Krall and Svetlana Alexievich - Krall originating from Poland and Alexievich from Belarus - who present peculiar strategies in presenting reality to the reader.

Aside from being well-recognized authors within their national literary and journalistic traditions, both Krall and Alexievich have as a common trait the protagonism of women during major 20th century European traumas - particularly World War II, the Holocaust, and the Chernobyl disaster. We intend to distinguish the particularities of style and voice in each author, their narrative and discursive strategies, and the way they present non-official points of view in opposition to the reproduction of ideologies connected to governmental or financial institutions - a main characteristic of literary journalism (Passos, 2017). In particular, we consider the way Krall and Alexievich reconstruct events in the lives of women in a way that allows for a simulation of the protagonists' experiences in the act of reading.

Under this premise we have analyzed Alexievich's Chernobyl Prayer (2016) - published as Voices from Chernobyl in the USA and The Unwomanly Face of War (2017), and Krall's anthology The Woman from Hamburg and other true stories (2005). Close readings of chapter excerpts serve as the basis for the discussion presented here. We understand close reading after Richards (2017, p. 195), who defines it as a kind of reading that is attentive to the nooks and crannies of a text, a way of identifying in details and specificities the clues for deciphering and characterizing textual strategies in a broader scope. It is necessary to state here that such analysis faces some restrictions since we are dealing with not with the original words and sentence structures, but with the choices of translators in their attempt to reconstruct - and even recreate - Alexievich's and Krall's works in English. Finally, we discuss their works and approaches to the experience of reality.

\section{Hanna Krall: Gaps and hush}

Born in 1935 in Warsaw, Hanna Krall is considered one of the founders of Polish reportage (Frukacz, 2019) and is a major influence on writers of younger generations such as Mariusz Szczygieł, author of Gottland (2014). Krall was the sole survivor of a Jewish family massacred during the Holocaust. She was rescued from a vehicle that transported Warsawian Jews to the ghetto where they were confined against their will, and later sheltered and hidden among the "Aryan" 
Polish population (Culture.pl, n/d). Krall recognizes her childhood experience as valuable and unique, giving her a precocious maturity and an unmatched ability to understand her characters - most of them also Jews (Ogiold, 2001).

Krall began her career as a reporter at the age of 20 in the daily newspaper Zycie Warszawy, and in 1966 she became a correspondent in the USSR for the Polityka magazine. Part of the reporting she wrote during her four-year stay in the country was published in 1972 in the book Na wschód od Arbatu [East of Arbat]. Her first piece of significant impact would be published in parts in the Odra magazine in 1976 and in book form in the following year under the title Zdażyć przed Panem Bogiem [Stand Before God]. The story featured Marek Edelman as its protagonist, one of the leaders of the Warsaw Ghetto Uprising, which attempted to resist the transference of its inhabitants to the Treblinka concentration camp.

Over the following decades, Krall would alternate jobs as a freelancer reporter with regular positions in newspapers and magazines, and develop a narrative style that could shock Tom Wolfe (2005) for the differences it had in comparison to the New Journalism - and literary journalism in a broader sense - in which events that were witnessed or reported were reconstructed in detailed scenes, rich in descriptions with the purpose of characterizing the way of life of its characters. Krall's style follows a distinct path in which the narration of events seems to be reduced to a bare minimum, its essentials, with a Kafkaesque raw use of language, regularly skipping months or even years every other paragraph; also suggesting actions, reactions and feelings in a way that makes the depiction of events - even major ones - ambiguous and unclear (Tatar, 2014). She also tends to transfer essential information from a most explicit position in the text to a gap that must be filled by the reader, loose ends one should tie by oneself (Iser, 1976), interspersed with personal comments.

Krall thus adopts a strategy in which the author does not disappear behind the story and let it flow "naturally", instead making it evident that her narrative is a reconstruction - an artifice that evokes "defamiliarization", as Shklovsky (2013) would say. Her approach might be considered closer to the "modernist" literary journalism (Eason, 2008) - one in which the author's voice is not that of an essayist who openly interprets reality, but of a designer or craftsman who lets the world know of their presence and influence in the shaping of the artwork through sudden "cuts" in actions and scenes and omissions of informa- 
tion that would be considered essential for most reporters and readers. In her view, even when applied to fiction works such technique would make a narrative more truthful, since the act of interpreting, explaining and organizing events in a logical manner would be untruthful:

My work as a reporter has taught me that logical stories, without riddles and holes in them, in which everything is obvious, tend to be untrue. And things that cannot be explained in any fashion really do happen. In the end, life on earth is also true, but it cannot be logically explained. (Krall, 2005, loc. 2040)

That is her approach in the pieces published in Taniec na cudzym weselu [Dancing at Someone Else's Wedding] (1993), an anthology of reportage partially reproduced in the book The Woman from Hamburg and Other True Stories (2005), the English language translation used as a source here 4 . Both anthologies contain stories about Jews who faced the Holocaust or Jewish everyday life before 1939 - the major theme in her body of work (Pluwak, 2015; Kilanowksi, 2013). Krall's literary journalism is based on documented research and conversations - a word she prefers to interview - that Krall had with several of the subjects who became her characters.

The piece "Ta z Hamburga" [The Woman from Hamburg] presents a plot that finds some parallels in Margaret Atwood's The Handmaid's Tale (1985). In her dystopia, fertile women are forced to become pregnant in place of the barren wives of the men from the militia that took over the government, and are dismissed after they give birth. In Krall's reportage readers meet Regina, a German Jew who is sheltered from Nazi persecution by Barbara and Jan, a married Polish couple who lived in Lviv, Ukraine. For over a year she spends most of her hours each day in a wardrobe, so that she could hide from any guest that might denounce her. Regina becomes pregnant with Jan's child and Barbara, after being threatened by her husband, hushes over it and starts to emulate her own pregnancy by wearing pillows under her clothes. When Helusia is born, Barbara takes her and presents her to the neighbors as her own daughter. A few days later, when the baby is baptized the sentence that contains the name of the diocese is the only moment

4 Which also collects some of the pieces originally published in Dowody na istnienie [Proofs of Existence] (1995). 
in the text that informs the place where this part of the story happens - the couple offers a reception for a few guests that lasts until dawn. Regina, who had given birth not long before, spends the whole time in the wardrobe. Months later, when the Soviet Army retakes the city, she disappears.

After this, there are several jumps in time that mark the way the relationship between the three women - Barbara, Regina and Helusia is woven across the years. The family returns to Poland and Jan becomes obsessed with the idea of finding Regina; he is visited by two men sent by her who tried to recover the baby. Helusia starts receiving mail packages with gifts from Hamburg, and Barbara starts referring to Regina, who is sending them, as Helusia's godmother. At first the packages are deeply annoying to her, but later she starts telling her daughter to ask for some items - e.g. cloth for her First Communion dress. Regina and Helusia then start to exchange letters - in truth, Helusia writes letters while Regina only sends gifts and checks, occasionally adding a photograph of herself - but they only meet in person twice. Their first meeting happens when, at the age of 25, Helusia is told that Regina is her mother; the second takes place 22 years later, when Regina invites her to spend some days in her home. Both encounters end in Regina's anguished breakouts, when she asks her daughter to not come see her again, since her presence makes her reexperience the affliction and fear from her past.

Krall's textual strategy, as previously indicated, uses distancing strategies and works with information gaps and clues to decipher them - a mechanism that, according to Wolfgang Iser (1976, p. 225), promotes a higher level of interaction between reader and text, making for a more active reading. The reader does not learn the professions of the characters or how they lived in the moment they were interviewed, and neither learns of their existence in a broader scope: only their roles in the development of the core events matter to the story.

In this sense, the reader's attention is drawn to the characters' hushings - one of the types of gaps present in the story, present in the way some characters hide essential information from each other, or refrain from confronting each other - and also to the tiny clues that may lead readers to reach some conclusions. One such clue appears when Helusia confronts Regina for the first time and the latter starts to obsessively repeat some sentences, while the former bursts into tears. Some of the dialogue lead us to the conclusion that Jan's and Regina's affair was not of mutual consent: "It's true. I gave birth to you (...). I had to. I had 
to agree to everything. I wanted to live. I don't want to remember your father. I don't want to remember those times. I don't want to remember you, either" (Krall, 2005, loc. 155).

Hushings, by their turn, are more noticeable in the actions of both Helusia's mothers. One of the first examples appear when Barbara finds out about Jan's adultery:

One summer day, the wife came home from shopping. Her husband's jacket was hanging in the anteroom; he had come home from work a little earlier than usual. The door to the Jewess' room was locked. One autumn day her husband said, "Regina is pregnant." (Krall, 2005, loc. 92)

In this excerpt Krall does not highlight in text something that seems obvious to the reader; on the contrary, refraining from stating it emulates Barbara's silence on the matter, even before she was threatened by Jan. This behavior is mirrored by Regina, who only spoke when she was addressed by someone - alluding to the oppression to which both were submitted, be it under the Nazis, under Jan, or, in a broader sense, under a society with no gender equality.

Krall's narrative strategy allows the reader to feel and testimony the oppression and despair experienced by her characters - especially in Regina's obsessive repetitions - precisely because it does not state that a given environment was oppressive or that a given action was desperate: the reader's interaction with the text via the information gaps and the conclusions reached are what position readers to become involved and immersed in the events and characters, all of which seem to be subjected by a tragic fate, as noted by Kilanowski (2013).

\section{Svetlana Alexievich: Memories and Feelings}

Born in 1948 in West Ukraine, Svetlana Alexievich achieved a BA in Journalism at the Minsk University and began her career in the letters section of a newspaper of collective farms: Сельская Газета [Rural Newspaper]. Later she was a reporter for other small newspapers and then a correspondent for the literary magazine Неман [Neman]. Alexievich has published six books, the most recent of which is Время секонд хэнд [Second-Hand Time], published in 2013, where she explored the fall of the USSR through several perspectives; the book also absorbed the entirety of her 1993 work Зачарованные смертью [Enchanted With 
Death], in which she discussed suicide among the Soviet youth. Alexievich also published the 1997 book Чернобыльская молитва [Chernobyl Prayer], where she collected testimonies by people involved in the aftermath of the disaster in the nuclear power plant, and the 1989 book Цинковые мальчики [Boys in Zync] on the 1979-1989 war in Afghanistan, whose title was a reference to the material covering the corpses brought back from the battlefield. In 1985 she released her first two books, Последние свидетели: сто недетских колыбельных [Last Witnesses: A hundred lullabies not suitable for children], which dealt with children who became orphans due to warfare, and У войны не женское лицо [War does not have a woman's face, published in English as The Unwomanly Face of War], which dealt with women soldiers in World War II.

Alexievich uses the same strategy for narrative and information gathering across her work: after collecting testimonies, she weaves them together in articulated polyphonic narratives which mostly regard the inner, non-official life affected by events that were traumatic for the soviet life. Her books are collections of monologues, with varying degrees of commentary by herself, a strategy that seems derived from what Kapuściński did in Cesarz [The Emperor] - which is not a coincidence, since both Kapuściński and Krall are recognized as major influences in Alexievich's reporting methods and style (Culture.pl, Oct. 13 2015). Also, books such as Unwomanly Face of War and Chernobyl Prayer are innovative in the way they depict women as protagonists in war and in disasters - either as combatants, victims or operational personnel, while most accounts of such events used to be gender-blind (Novikau, 2017).

In her introduction to The Unwomanly Face of War, Alexievich offers excerpts from her writing journal that reveal some thoughts that guided her creative process. She states that during her childhood she heard from the women in her village, especially her mother and grandmother, a version of WWII which differed considerably from what was written in books - a canonic approach full of "masculine" words. For Alexievich,

"Women's" war has its own colors, its own smells, its own lighting, and its own range of feelings. Its own words. There are no heroes and incredible feats, there are simply people who are busy doing inhumanly human things. And it is not only they (people!) who suffer, but the earth, the 
birds, the trees. All that lives on earth with us. They suffer without words, which is still more frightening. (Alexievich, 2017, p. xv)

In order to organize a narrative strategy fit to give voice to people who were silenced, Alexievich created a special environment that overvalued a "neutral" version of History, offering a counter, humane, version of events.

More than once afterward I met with these two truths that live in the same human being: one's own truth driven underground, and the common one, filled with the spirit of time. The smell of newspapers. The first was rarely able to resist the massive onslaught of the second. (Alexievich, 2017, p. 88)

On the one hand, Alexievich's book portrays the atrocities of war: torture and mutilations; the lives of prisoners; hate, death and rape; the hand-to-hand combat that scarred the memories of several deponents with the sound of bones breaking; the hardships of winter and of missions. However, on the other hand, the book also covers topics such as the will to wear dresses and make-up; the inability of soldiers in dealing with their periods; a wedding dress made of bandages; the story of a woman for whom wearing boxers was the worst thing in war; and love. All this helped weave what Sara Danius, Permanent Secretary of the Swedish Academy, has labeled as "a history of emotions - a history of the soul, if you wish" (Gessen, 2015).

In the third chapter in the book, "I Alone Came Back to Mama", Alexievich meets Sergeant Major Nina Yakovlevna Vishnevskaya, a medical assistant in the 32th Tank Brigade of the 5th Army. Nina took part in one of the biggest tank battles in world history, near Prokhorovka. Alexievich notices that all the books and decorative objects in Nina's home are related to war: dolls wear military uniforms; the wallpaper is khakhi; the horns of an elk are used to hang a helmet. In her testimony, Nina explains how the girls were excited to enter the army but were accepted only reluctantly by their peers. There was curiosity and shock among the newcomers in the battalion. It took some effort for her to be accepted in the tank battalion due to her height of $1.60 \mathrm{~m}$, since it would present some difficulties. As a captain in the battalion told her 
while justifying his refusal of admitting her in his unit, when a soldier gets wounded inside the tank,

he has to be pulled out of it through the hatch. How are you going to do that? Tank soldiers are all big and sturdy, you know. You have to climb up on the tank, it's being shelled, there are bullets, shells flying. And do you know how it is when a tank catches fire? (Alexievich, 2017, p. 79)

Stories like this are present throughout the book in order to highlight one of the "unwomanly" aspects of war: the rejection or contempt men had for women soldiers, even those who were supposed to be their fellows in the battlefield - which those believed not to be a proper place for women. It was not expected of them to fight alongside men, especially those who did not have a strong build. However, of all of her friends she described as more able than her, Nina was the only one to return to her mother.

Nina Vishnevskaya goes on to tell about the women soldiers' preoccupations with military hairstyles and uniforms designed only for men. It was also difficult to understand some military visual codes, since they were not sufficiently instructed about them. "For us girls, everything in the army was difficult. It was very hard for us to sort out the different insignia. When we came to the army, there were still diamonds, cubes, stripes, so just try figuring out what his rank is." In the end, "What we remembered was not whether this or that officer was a lieutenant or a captain, but whether he was handsome or not, red-headed, tall..." (Alexievich, 2017, p. 82). Nina also talks about love, such as the relationship between a friend of hers and another soldier, and Nina's discovery of her own sexuality when a lieutenant approaches her before a dangerous attack. All of those aspects unveil aspects of everyday life in the army, of "everyday ideology" or "behavioral ideology" (Volóshinov, 2015), or the way personal and collective experience gives meaning to places, objects, people and actions. In this case, the unfamiliar and sterile environment is re-signified and is given another layer of life. Prejudice against women, as well as women's actions and ways of re-signifying the experience of war, seem to be the main themes of the book.

Chernobyl Prayer, by its turn, deals not with the explosion of the fourth reactor of the Chernobyl nuclear power plant near the border of Ukraine and Belarus, but rather with the disruption of thousands of lives 
caused by the explosion and radioactive poisoning, through the monologues of farmers, doctors, villagers, midwives, engineers, liquidators, teachers, mothers and fathers, husbands and wives - people forced to move away from their homes or who kept living in contaminated areas. In a broader sense, it is a book about everyday ideology; that is, the voices and values of people which are out of reach or even clash with the voices and values of administrative, scientific and coercive powers (Volóshinov, 2015). Even the experts who give their testimony in the book play the roles of witnesses - people who acted amid the chaosinstead of distant analysts.

The book's overture chapter, titled "A Lone Human Voice", is the monologue of Lyudmila Ignatienko, wife of Vasily, one of the firemen who were called to put down the fire in the power plant and seal the reactor. Her narrative is constantly punctuated by her remarks on the omissions of the public agents. Lyudmila's husband was called to put out what he thought to be an ordinary fire and sent to his mission, along with his comrades, without any kind of special protection, being exposed to a dose of radiation four times higher than what is considered lethal for a human being. This lack of care was extended to the medical team in the first hospital where they were treated: "Later, lots of the doctors and nurses in the hospital, and especially the orderlies, came down sick. They died. But back then, nobody knew that would happen" (Alexievich, 2016, loc. 199). Confusion and misinformation increased when the army arrived, washing the streets with a strange white powder and wearing gas masks. The actions of the army became authoritarian when the firemen were moved by force to Moscow - an operation not much different from kidnapping:

In the evening, they wouldn't let us into the hospital. There was a whole sea of people. I stood outside his window, he came over and was shouting something to me. Shouting desperately! Somebody in the crowd heard him: they were being moved to Moscow that night. The wives all huddled together. We decided we were going with them. 'Let us see our husbands!' 'You can't keep us out!' We fought and scratched. The soldiers were pushing us back, there were already two rows of them. Then a doctor came out and confirmed they were being flown to Moscow, but he said we needed to bring them clothes - what they were wearing at the power station had all got burned. There 
were no buses by then, so we ran, all the way across town. We came running back with their bags, but the plane had already gone. They had done it to trick us. So we wouldn't shout and weep. (Alexievich, 2016, loc. 206)

Lyudmila managed to travel to Moscow with her in-laws and found the clinic where the firemen were allocated; in order to go inside and see her husband again, she had to bribe a guard and hide her pregnancy. Once she got inside, she hugged him as much as she could. Nurses and doctors tried to keep her away from him but took a long while to explain why: "He isn't a person now, he's a nuclear reactor. You'll both frazzle together" (Alexievich, 2016, loc. 351). She witnessed his emaciation, the detachment of mucosas and skin; and in the end she also lost her baby daughter, who was stillborn. Her monologue, like all the others in the book, portrays the events in Chernobyl not as an environmental disaster, but as a personal and psychological tragedy.

Again, this is exemplary of "everyday ideology". While the book lacks a unified narrative progression - the testimonies in each chapter are a part of a fractal structure that seems to be built upon a single theme: the tension between a government and its people. This tension exists between authorities who try to conceal - even from themselves the reality of the events and stakes involved in the tragedy, who seem to look at it from a distance at which common people are virtually invisible, and the people who demand to know what is actually happeningwho unknowingly march towards their deaths, who tell the reader how life actually is at the level of personal and collective experience. Again, through their points of view, global, environmental tragedy becomes personal drama. It is now tangible, relatable. The fractal structure of the book is, in a sense, a way of stating how impossible it is to simplify reality, to give it an orderly and cohesive form - each testimony is a piece in a larger story which will never be known in its entirety, since that would require interviewing every person who was involved or affected by it.

\section{Different approaches, similar themes}

Although the narrative strategies used in The Unwomanly Face of War and Chernobyl Prayer are different, Alexievich's writing operates in same direction, which is in opposition to that of Krall's writing, featuring longer scenes, richer in detail, and thus representing a virtual 
testimony of events. This arguably opens the opportunity for immersion in the narrative for the reader, for imagining being a part of it, for experiencing the events like an eyewitness would, for getting involved with them (Knorr-Cetina, 1999). In Chernobyl Prayer the role of reader as eyewitness is emphasized by the aesthetic and structural choices made, by writing each chapter in first-person under the point of view of the characters Alexievich interviewed, in order to recreate events (Hartsock, 2015; González González, 2018). Krall, on the other hand, alienates the reader from the events described: the fruition of her reporting is more analytical than engaging.

The difference in their approaches is clearer understood if we compare two excerpts in which both authors deal with similar events - the drowning of a hungry child and the abandonment of a toddler on the street during a pursuit by Nazi troops. The excerpt by Alexievich is part of the chapter "From a conversation with the censor" in The Unwomanly Face of War:

Somebody betrayed us... The Germans found out where the camp of our partisan unit was. They cordoned off the fort and the approaches to it on all sides. We hid in the wild thickets, we were saved by the swamps where the punitive forces didn't go. A quagmire. It sucked in equipment and people for good. For days, for weeks, we stood up to our necks in water. Our radio operator was a woman who had recently given birth. The baby was hungry... It had to be nursed... But the mother herself was hungry and had no milk. The baby cried. The punitive forces were closed... With dogs... If the dogs heard it, we'd all be killed. The whole group - thirty of us... You understand? The commander makes a decision... Nobody can bring himself to give the mother his order, but she figures it out herself. She lowers the swaddled baby into the water and holds it there for a long time... The baby doesn't cry anymore... Not a sound... And we can't raise our eyes. Neither to the mother nor to each other... (Alexievich, 2017, p. XXXIII)

The following excerpt by Krall, on the other hand - a long testimony, atypical to her style - is part of Dybuk [The Dybbuk], one of the pieces originally collected in the book Dowody na istnienie [Proofs of 
Existence] and selected for the anthology The Woman from Hamburg and other true stories. It presents an interview with Adam S., a baby boomer American who was the son of Polish Jews, and whose halfbrother was sacrificed for the survival of his father's group, which was hiding from persecution by Nazi soldiers:

Yes, in a phone conversation. He was living in Iowa; I called him after I got back home. I thought he wouldn't believe me, that at the very least he'd be taken aback, but he wasn't taken aback at all. He listened calmly, and then he said, "I know what that cry is. When they threw him out of the hiding place he stood in the street and cried loudly. That was the cry - the cry of my child who was thrown out into the street."

This was the first time I had talked with my father about my brother. Father had a weak heart; I didn't want to upset him. I knew that my brother had died, like everyone else; what more was there to ask about? Now I found out that the boy had been hidden somewhere with his mother, my father's first wife, along with a dozen or so other Jews. I don't know where, if it was in the ghetto or on the Aryan side. Sometimes I picture a kitchen and people crowded together. They were sitting on the floor, trying not to breathe. He started crying. They tried to quiet him. How do you calm a crying child? With candy? A toy? They didn't have toys or candy. His crying grew louder and louder, and the people crowded together on the floor were thinking the same thought. Someone whispered: "We're all going to die because of one little kid." Or maybe it wasn't a kitchen. Maybe it was a cellar, or a bunker. My father wasn't with them; only she was, Abram's mother. She stayed with the others. She survived. She settled in Israel, maybe she's still living there, I didn't ask, I don't know.... My father died. (Krall, 2005, loc. 1521)

While both deal with similar situations - people in despair and struggling for their lives - and follow similar broader aesthetics of testimonial report, the stylistic choices are distinct. Here the influence Krall had over Alexievich becomes clearer (Culture.pl, Oct. 13 2015). 
Alexievich reconstructs the experience of the event in a more traditional approach - one might call it a "mastery of storytelling" - imbuing it with a dramatic crescendo in which the hardships, the impending threat of the troops, and the lives at stake stack up on top of each other in order for the commander's decision to be completely understandable, while we as readers are positioned to feel sorry for the mother. It is a logical, passionate, thrilling entanglement of issues - a "realist" storytelling in which the author is detached from the events and the interpretation of the events, while her characters take the lead and seem as if they are speaking directly to the reader, like a first-hand confession.

Krall, on the other hand, presents a second-hand testimony - a father's testimony reconstructed by his son - or what Kilanowski calls "crooked second-hand memories" (2013). The account loses most of its tension as the telling of the event is preceded by its ending - the abandonment of the toddler on the street - and as it is constantly interrupted by remarks regarding uncertainties about the space where the event had happened, or the fate of Abram's mother. This fate remains unknown mostly due to the narrator's unwillingness to interrogate his fatheranother recurrent form of hushing present in Krall's work.

In this sense, Krall sails against the current of some of the essential values of reporting, such as precision of information (Sims, 2007). However, as we have noted, she uses imprecision as a strategy for promoting a more active interaction between reader and text. The core of the information is still there but is not evident - sometimes the reader needs to dig it out, and sometimes intuit the truth. The world she reconstructs in text is a complex, shattered mosaic in which the reader's process plays a major role in gathering pieces together and giving them meaning.

Some form of hushing appears as a common theme to both reporters: women, in particular, seem to be abandoned through refusal to give them notice of events, often keeping essential facts from them. The women, by turn, have to hush and omit information in order to survive. From these commonalities of textual representation, the stories of Slavic women appear as the narrative of suppression of their experience - their struggles and achievements as well as their oppression-by chauvinist societies, and, on the other hand, the narrative of their hushing in social contexts where it was already expected that women would be silenced and their points of view ignored. 


\section{Pushing the boundaries of literary journalism}

In Literary Journalism and the Aesthetics of Experience, John Hartsock (2015) discusses the pact literary journalism establishes with readers, offering up a more involving narrative approach to facts which might improve the reader's perception and understanding of events due both to the aesthetics of narrative and to the assumption that every action and thought was fact-checked and truthful, i.e., that it was unequivocally "real".

As Hartsock (2015, p. 82) himself has noted, however, there is some degree of elasticity to literary journalism, and Alexievich's style differs considerably from much canonical literary journalism by not using conventional narrative progression throughout the larger scope of the books, especially in the case of her later works - although narrative progression is evident in each of the testimonies. She also removes herself from the surface of the narrative as a mediator and emulates a situation in which the people she has interviewed seem to tell their stories by themselves, as if directly addressing the reader - albeit with precision regarding time and place, and still featuring more usual storytelling techniques. These stylistic features contribute to an intimate but still unequivocal reading experience in which the reader might feel as if he or she were the person who was interviewing the character, rather than witnessing the events.

The strangeness caused by Hanna Krall's approach to the experientiality of events is stronger and deeper - especially due to the hushings, the omission or lack of information, the dubiousness, ambiguity and opacity of actions, feelings and even the time and space where actions have taken place. It strongly defies its status as journalism by being deeply literary, by Krall's belief that presenting a succession of events as logical and unequivocal facts would be untruthful, both to the way memory works and to the ways people experience the world. This is what seems to be her goal: aesthetically recreating in narrative the way her characters experience reality, denying the cause-effect logic and the data-rich, meticulous explanation we expect to find in journalism - while still being truthful enough to her sources and observations to be considered a journalist by her peers. The impact of her innovation can even be felt in the way most Polish reporters flirt with the ambiguity between fact and fiction, literature and journalism (Frukacz, 2019).

A reader of Svetlana Alexievich faces the task of grasping a broader sense of reality from the fractal of testimonies, the mosaic of 
individual experiences; a reader of Hanna Krall is called to resign themselves to the unreachability and fictionality of a total understanding of reality in her work.

\section{References}

Alexievich, S. (2016). Chernobyl Prayer. New York: Penguin (ebook).

Alexievich, S. (2017). The Unwomanly Face of War. New York: Random House.

Atwood, M. (1985). The Handmaid's Tale. Toronto: McClelland \& Stewart.

Bak, J. S. (2011). Introduction. In Bak, J. S., \& Reynolds, B. (Eds.) Literary Journalism Across the Globe (pp. 1-20) Amherst: University of Massachussetts Press.

Bakhtin, M. (2016). Os gêneros do discurso. São Paulo: Editora 34.

Caracciolo, M. (2014). The Experientiality of Narrative: An Enactivist Approach. Berlin: Walter De Gruyter.

Culture.pl. Hanna Krall. Retrieved from: https://culture.pl/en/artist/hanna-krall

Culture.pl. 2015 Nobel Laureate Alexievich Discusses Polish Influences. Oct 132015. Retrieved from: https://culture.pl/en/article/2015-nobel-laureate-alexievich-discusses-polish-influences

Eason, D. (2008). The New Journalism and the Image-World. In Sims, Norman (Ed.). Literary Journalism in the Twentieth Century (pp. 191-205). Evanston: Northwestern University Press.

Frukacz, K. (2019). Literary Reportage or Journalistic Fiction? Polish Reporters' Struggles with the Form. Literary Journalism Studies, 11(1), 7-34.

Gessen, M. (2015). The Memory Keeper. The Oral Histories of Belarus's New Nobel Laureate. The New Yorker, Oct. 192015.

González González, D. (2018). The Testimony of the Vestige in Chernobyl Prayer: A Chronicle of the Future by Svetlana Alexievich. IC - Revista Cientifica de Información y Comunicación, 15, 147-173.

Hartsock, J. C. (2015). Literary Journalism and the Aesthetics of Experience. Amherst: University of Massachussetts Press, 2015.

Iser, W. (1976). Der Akt des Lesens: theorie asthetischer Wirkung. München: Wilhelm Fink.

Kilanowski, P. (2013). Hanna Krall e os caminhos tortos da memória e da identidade. Aletria, 23(2), 151-163.

Knorr-Cetina, K. (1999). A comunicação na ciência. In Gil, F. (Ed.). A ciência tal qual se faz (pp. 375-393). Lisboa: Edições João Sá da Costa.

Krall, H. (2005). The Woman from Hamburg and Other True Stories. New York: Other Press (ebook).

Novikau, A. (2017). Women, Wars and Militarism in Svetlana Alexievich's Documentary Prose. Media, Wars \& Conflict, 10(3), 314-326.

Ogiold, K. Mózg to jest przereklamowany organ. Nowa Trybuna Opolska, 2 nov. 2001. Retrieved from: http://www.nto.pl/artykuly-archiwalne/art/3948257,mozg-to-jest-przereklamowany-organ,id,t.html.

Passos, M. Y. (2017). De fontes a personagens: definidores do real no jornalismo literário. In: Soster, D. A. \& Piccinin, F. (Eds.). Narrativas midiáticas contemporâneas: perspectivas epistemológicas (pp. 86-97). Santa Cruz do Sul: Catarse. 
Pluwak, A. (2015). Ambiguous Endeavours: The Evolution of the Melodramatic Mode in Polish Holocaust Narratives from Hanna Krall to The Aftermath. Lund: Lund Slavonic Monographs.

Richards, I. A. (2017). Practical Criticism. London: Routledge.

Shklovsky, V. (2013). A arte como procedimento. In: Todorov, T. (Ed.) Teoria da literatura - Textos dos formalistas russos (pp. 83-108). São Paulo: Editora Unesp.

Szczygieł, Mariusz (2014). Gottland: Mostly True Stories from Half of Czechoslovakia. New York: Melville House.

Sims, N. (2007). True Stories: A Century of Literary Journalism. Evanston: Northwestern University Press.

Tatar, A. (2014). Paraboliczne opowieści o ukrywaniu się w szafie:Ta z Hamburga Hanny Krall i Daleko od okna Jana Jakuba Kolskiego. Rocznik Komparatystyczny, 5, 281-312.

Volóshinov, V. (2015). Marxismo e Filosofia da Linguagem. São Paulo: Editora 34.

Wiktorowska, A. (2014). Ryszard Kapuściński: visión integradora de un reportero. Clasificación, construcción y recepción de su obra. PhD Dissertation, Construció i Representació d'Identitats Culturals, Universitat de Barcelona.

Wolfe, T. (2005). Radical chique e o Novo Jornalismo. São Paulo: Companhia das Letras.

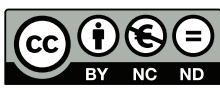

«Attibution - pas d'utilisation Commerciale - Pas de Modification 4.0. International» (CC BY-NC-ND) 